Article

\title{
Service Quality and Service Gap of Autonomous Driving Group Rapid Transit System
}

\author{
Wei-Hsi Hung $(1)$ and Yao-Tang Hsu * \\ Department of Management Information Systems, National Chengchi University, Taipei 11605, Taiwan; \\ fhung@nccu.edu.tw \\ * Correspondence: Hsuyaotang1226@gmail.com; Tel.: +886-02-2909-7811-1521; Fax: +886-2909-5888
}

Received: 28 September 2020; Accepted: 8 November 2020; Published: 12 November 2020

\begin{abstract}
Recently, the trend of public transportation has evolved from traditional vehicles to intelligent transportation systems. Among many innovative systems, the development of group rapid transit (GRT) has become increasingly important. This study aims to explore the key acceptance factors for users to adopt GRT through three dimensions: technology, sharing, and experiential marketing (TSE). First, this study identifies variables under each construct of the TSE model through a literature review and interviews with experts, so as to understand what factors of the model impact users' usage intention and continuous usage intention. Subsequently, through a questionnaire survey, the theoretical model is verified. The participants of the survey were users of GRT, and a total of 306 valid questionnaires were collected. Through structural equation modeling (SEM) analysis, the results indicate that technology does not significantly impact usage intention, as users may not fully understand GRT's future developments; technology only affects continuous usage intention. Sharing also only influences continuous usage intention. These results show that the adoption of GRT may be gradual and long-term rather than short-term. Finally, experiential marketing has a significant impact on both usage intention and continuous usage intention. This implies that users' experiences are vital in promoting innovative services, hence service providers should seek to not only improve the service but also enhance users' trust in and support for the service.
\end{abstract}

Keywords: group rapid transit; technology acceptance; sharing economy; experiential marketing; usage behavior

\section{Introduction}

In recent years, traditional transportation has evolved into intelligent transportation systems. Group rapid transit (GRT), an innovative transportation service system model, is one such system; it is an important development trend as well as an emerging industry. Different from mass rapid transit (MRT) or general bus rapid transit (BRT), GRT is an unmanned driving system in which the vehicle sizes can be adjusted to suit different periods (peak or off-peak). In addition, during off-peak hours, due to the unmanned driving system, service can be provided through a system similar to taxi hailing [1-3].

At present, companies and governments across the world are actively introducing GRT service, and various tests are being carried out in different countries to determine its applicability. In 2016, Sion in Switzerland took the lead in using unmanned vehicles for public transportation. In 2019, Nanyang Technological University launched a GRT system on campus as part of its efforts to enhance the living and learning experience using technological solutions [4]. Subsequently, in 2020, Newcastle introduced the first unmanned vehicle to provide passenger service on general roads [5].

In Taiwan, the Hsinchu area signed a contract with a Dutch GRT company in 2015, hoping to solve the urban traffic congestion problem. The GRT was expected to carry 4800 passengers per hour [6]. 
In 2017, National Taiwan University introduced an unmanned bus, EZ10, on its campus, which was the first electric autopilot bus in Taiwan. Its operation mode is similar to GRT, with electricity controlled from the cloud and passengers picked up at designated points [7]. In 2020, Taoyuan International Airport will trial the operation of unmanned autopilot shuttles as part of its efforts to automate the amenities at the airport [8].

To investigate users' usage intention and continuous usage intention, this study proposes a technology-sharing-experiential marketing (TSE) framework that is more compatible with the GRT service system to explore the impact of technology, sharing, and experience on the usage of GRT. The TSE framework is based on the technology-organization-environment (TOE) model [9], a framework that is more suitable to explain the impact of those three factors on the information technology acceptance of enterprises. Since GRT is a shared service system, the TSE model can emphasize consumers' acceptance of the sharing economy model and the experiential marketing activities of the innovative technology.

In the past, most of the studies on usage intention and continuous usage intention were aimed at exploring the field of networks and information systems [10-13]. However, they did not address innovative service applications such as GRT. Given the trend of GRT, this study focuses on its key acceptance factors through the TSE model. The study also examines the key factors of the model that influence usage intention and continuous usage intention.

\section{Literature Review}

\subsection{GRT}

Group rapid transit (GRT) and personal rapid transit (PRT) are sub-categories of autopilot public transportation systems. PRT is an emerging urban transportation mode that uses small computer-assisted vehicles for transportation via rail networks and paired stations. Vehicles provide direct services from origin stations to destination stations, in line with passengers' requests [14]. Since GRT runs on electricity and does not require mechanical equipment, the vehicle weight is lighter. Besides, the savings on infrastructure costs enable the PRT design to focus on improving passengers' experience and comfort and the intelligent automation system [15].

GRT is an unmanned automated driving system similar to PRT, but it has the capacity to carry more passengers. It is like a horizontal elevator system that optimizes public transportation, effectively reduces travel time, and saves resources [15]. GRT can adapt the size of vehicles according to different times and on-peak/off-peak hours. It also provides a service similar to taxi-hailing during off-peak hours. However, it is not mass rapid transit, as the compartment capacity is about 10-50 passengers. Most GRT systems use off-line stations and provide services for passengers with the same stops. Hence, passengers do not need to wait for a long time, unlike shuttle buses.

Muller and Andreasson [3] noted that compared to general rail systems, the average waiting time for GRT is $2.5 \mathrm{~min}$, the maximum waiting time is $5 \mathrm{~min}$, and the weekly passenger capacity is 20,370. In addition, to improve its efficiency, GRT provides regular or on-call services based on customer needs [3]. In addition, GRT can bypass the main routes and drive on any road sections. It has more advantages in terms of technology, economy, and operation compared to traditional public transportation [15]. GRT can not only reduce the cost of hiring drivers but also respond to environmental issues, such as reducing noise pollution and carbon dioxide emissions [16]. It can also reduce $70 \%$ of the carbon footprint compared to gas-powered automobiles and $50 \%$ of carbon emissions compared to buses and trains [15].

Regarding sustainability, as environmental aspects of urban settlements has gained strength and significance, technology usage has been found to be related to environmental problems and sustainability [1]. According to López-Lambas and Alonso [17], autonomous driving is energy-wise more efficient and controlled. Vehicles of GRT systems apply eco-driving patterns and are programmed to minimize energy consumption by using electricity or cleaner fuels. They also analyzed the psychological factors affecting users' acceptance of automated mass transportation through focus group 
interviews. The most significant positive factors include reduced personnel costs, traffic congestion, waiting time, and carbon emissions. Moreover, the higher speeds of the GRT system also contribute to comparatively fewer vehicles, parking facilities and system operation being needed [3].

Through a large cross-national questionnaire, Nordhoff et al. [18] reported that usefulness and ease of use are the most influential factors that affect the public's acceptance of automated vehicles. Roche-Cerasi [19] found that safety concerns were the most significant constraint in promoting driverless shuttles in Norway. Thus, people will trust and accept the automation of public transportation if the risk of accidents is effectively addressed.

\subsection{TOE and Technology Acceptance Model}

Davis [20] proposed the technology acceptance model (TAM), which uses perceived usefulness and perceived ease of use to explain the intention to adopt information technology. Venkatesh and Davis [21] claimed that "social influence" and "perception of tool value" are two important dimensions that affect users' perception; they revised the TAM and formed a new model, TAM2. Additionally, Venkatesh et al. [22] proposed the unified theory of acceptance and use of technology (UTAUT) based on related research on TAM, which mainly focuses on performance evaluation and environmental impact before behavioral intentions. The latest revised model is the extended unified theory of acceptance and use of technology (UTAUT2) proposed by Venkatesh, Thong, and Xu [23], which is the most comprehensive model for exploring users' behavioral intentions and actual use.

Previous studies that explored the factors affecting the adoption of technology can be categorized in two levels: organizational and individual $[24,25]$. The problems encountered in organizations are more complicated, as organizations comprise multiple individuals. Additionally, decision-making is slower in organizations. Therefore, the technology-organization-environment (TOE) framework proposed by Tornatzky and Fleischer [9] includes technological, organizational, and environmental dimensions. The TOE framework has been widely used to discuss the acceptance of technological innovation and summarizes the factors affecting the acceptance of technological innovation into three categories: technology, organization, and environment. Technology refers to the internal and external technology of enterprises, including equipment and operating procedures. Organization refers to characteristics and resources of enterprises, including firm size, management structure, and human and financial resources. Environment refers to industrial scale, competitors, stakeholders (upstream to downstream suppliers) who obtain the supply of resources, and government relationships.

In the past, the TOE framework was widely used in technology acceptance by enterprises. Kuan and Chau [26] extended it to explore the acceptance of electronic data interchange technology by small enterprises. They studied 575 small enterprises in Hong Kong, and the results showed that the TOE framework explained the impact of enterprises on the acceptance of information technology. Zhu, Kraemer, and Xu [27] adopted the TOE framework to study organizations' acceptance of electronic enterprises. That study showed that the influencing factors included technical capability, organization size, customer readiness, partner readiness, and competitive pressure. Moreover, Hong and Zhu [28] extended the TOE framework to explore factors influencing the acceptance of Internet-based e-commerce. The results showed that the three dimensions of TOE were the key influencing factors for enterprises.

\subsection{Technology, Sharing, Experiencial Marketing (TSE)}

This study proposes the technology-sharing-experiential marketing (TSE) framework, which was derived from the concept of the TOE framework. Regarding the technology aspect, GRT is an innovative transportation tool that needs to be accepted by users. Regarding the sharing aspect, it is a kind of shared mobility that involves the concept of sharing economy. Regarding the experiential marketing aspect, to enhance the usage and continuous usage intention of users, it is crucial to engage their interest by connecting the individuals' needs and to arouse their desire for GRT through interactive experiences. In conclusion, the TSE framework is specific to research on the usage and continuous usage intention of GRT system. 


\subsubsection{Technology}

The first dimension of TSE is technology, which refers to all technologies related to products and services. In this case, GRT is an innovative transportation tool and users need to accept five dimensions of technology: perceived enjoyment, perceived ease of use, perceived benefits, technological capability, and availability. Perceived enjoyment emphasizes the feeling of pleasure while using the system. It is positively related to people's attitudes towards the continuous usage of innovative technology [29]. Perceived ease of use means that if users feel that the effort to use the system exceeds the benefits, they will tend not to use it [30]. Perceived benefits refers to the benefits that users believe can be obtained by adopting new technologies [31]. Technological capability involves the modification or improvement of innovative technologies; technological capability refers to the performance of a product or a service [32]. Availability refers to the capacity of a product or system to provide a complete technology portfolio [33].

\subsubsection{Sharing}

The sharing economy describes the connection of dispersed groups to promote a more effective use of goods and skills through networking technology. The concept of a sharing economy can be traced back to collaborative consumption, proposed by Felson and Spaeth [34], and can be regarded as a technological phenomenon of collaborative consumption [35]. Botsman [36] believes that collaboration and sharing are consistent since sharing is a necessary link during the process of collaborating. Relevant studies on collaborative consumption can be divided into three categories, as follows.

The first category refers to studies on consumers' acceptance of collaborative consumption models. These studies explored the factors affecting the satisfaction of new participants with sharing consumption models and consumers' motivation to participate and re-participate in sharing consumption [37]. The second category of studies refers to the key success factors of the collaborative consumption sharing model. These studies considered the continuous expansion and growth of the model and focused on innovative business model development in various industries [38]. The third category explored the service models of suppliers of collaborative consumption sharing. Through surveys of consumers who used sharing services, they discussed the economic benefits, trust, reputation, perceived ease of use, perceived uniqueness, environmental sustainability, and community value brought by collaborative consumption services. Additionally, they explored the influence of these factors on personal feelings (such as perceived value and customer loyalty) to reveal the determinants of customer loyalty in collaborative consumer services [39]. Their findings can help suppliers to understand the characteristics and real needs of consumers and provide products and services that better meet those needs.

The factors that affect collaborative consumption sharing can be divided into six categories. The first is community belonging. Members hope to get a sense of belonging during consumption, which is also a determinant of collaborative consumption [40,41]. The second category is environmental impact. In recent years, public environmental awareness has risen and anti-consumption, green, ethical, or sustainable alternative forms of consumption have received increasing attention [15,16,42-46]. Most importantly, rapid transit systems are using alternative fuels, propulsion systems and pollutant emissions controls [47]. While the expected reduction in emissions is the principal benefit, this kind of sharing vehicles can also lower overall noise levels as well as the production of both liquid and solid waste. The third category is reputation. People usually look forward to highlighting their contributions to promote their reputation. Therefore, self-marketing and reputation building are the most influential indicators in a sharing economy [35,48].

The fourth category is sustainability. Collaborative consumption has a positive influence on ecological sustainability $[49,50]$. It can act as a means that initiates the public's environmental and social awareness which induces sustainable consumptions [49]. Sharing economy is now a new sustainable business model that encourages the minimization of consumption and maximizes societal and environmental benefits [50]. This proceeds to the fifth category; social benefits. In the 
communication between customers and service providers, service quality has a decisive influence on customers' feelings. Thus, social benefits between customers and service providers are important [51]. The sixth category is trend affinity. Sharing consumption is an emerging trend that affects consumer behaviors on a large scale [36], especially young people, who tend to use innovative and fashionable products and services [52]. Moeller and Wittkowski [53] also found that young consumers who seek to use trendy products tend to share ownership.

\subsubsection{Experiential Marketing}

The term "experiential marketing," which combines experience and marketing, was first used in strategic experiential modules (SEMs) proposed by Schmitt [54]. SEMs are composed of five experiential types. The first type is "sense," which includes vision, sound, smell, taste, and touch. The goal of sensory experience is to provide consumers with a positive perceived experience through sensory stimulation. The second is "feel," which aims to create feelings and emotions ranging from a mild positive mood to strong emotions of joy and pride. The third is "think," which can inspire customers' creative perception and problem-solving ability. The fourth is "act," which enhances customers' physical experience enriches their lives by showing them alternative lifestyles and interactions. The fifth is "relate," which establishes a connection with others or social relations and culture. Therefore, it can achieve the ideal self and increase personal experience.

\subsection{Usage Intention, Usage, and Continuous Usage}

Chronologically, the use of information systems can be divided into usage intention, usage status, and continuous usage intention. Usage intention refers to a personal willingness to use a certain information system technology in the future. It is a possibility that someone will intend to adopt a technology or information system. Continuous usage intention is the willingness to adopt the system after trying it $[55,56]$. With reference to the factors influencing users' adoption of new technology, Sun and Jeyaraj [11] found that in the early stage, individuals' innovative attitude and characteristics will affect their intention to use new technology. In the later stage, their intention will be affected by their innovative attitude and contextual factors. Hsiao et al. (2019) confirmed that the quality of the technology system will positively affect users' willingness to continue to use the system.

Yoon, Duff, and Ryu [12] divided the factors that affect continuous usage intention into two types: external and internal motivation. Legault [57] claimed that internal motivation arises when participation behaviors are satisfying or pleasing, while external motivation refers to the fact that the performance of behaviors depends on the results achieved and is separate from the behaviors. Van der Heijden [10] believed that the perception of pleasure is focused on internal motivation, while the perception of usefulness is focused on external motivation. He suggested that for practical systems, external motivation can be used as the main predictor of system usage intention.

Past studies did not establish an integrated framework to reveal the relationship among antecedents, usage status, and continuous intention to use experiential marketing and sharing consumption while using GRT services. Therefore, this study aims to determine the key factors influencing users' usage status and continuous usage intention with regard to GRT services. Furthermore, this study provides an integrated model to understand the relationship between key variables and users' continuous usage intention.

\section{Research Methods}

In this study, through qualitative interviews, grounded theories, and questionnaires, variables within the TSE dimensions are summarized to establish the overall factors that affect users' usage of and continuous intention to use GRT services. First, 25 relevant variables were determined through literature reviews, to ensure that these variables are specific to the proposed model and are statistically significant according to past studies. This step helped to identify the most important and most common variables in the TSE model, and they were finally summarized into 16 applicable variables through a 
seminar attended by eight industry, government, and academic experts. The seminar was conducted by researchers and industry experts through face-to-face interviews. After the seminar, a preliminary TSE model (including dimensions and key variables within the dimensions) was constructed based on the literature review and experts' suggestions. Questions of each dimension in the first draft of the questionnaire were collected from a previous study related to the variables. By conducting a literature review, scales or measurements that could be applied or adapted were identified; furthermore, the items of each dimensions were ensured to be aligned with related theory and research in the field. To delete inapplicable questions and complete the final questionnaire, a pretest was conducted through interviews and discussions with academic experts. Finally, through the questionnaire survey with response options structured on a five-point Likert scale, the influence of variables on users' usage of and continuous intention to use GRT service under the TSE model was verified. Since no integrated framework or concept was proposed in past studies, it is difficult to understand the relationships among the three dimensions, their antecedents, usage status, and continuous usage intention.

This study aimed to determine the factors that affect users' usage intention and continuous usage intention with regard to GRT service and provide an integrated framework to explain these factors. Users' motivations for using information technology were first divided into three categories: technology, sharing, and experiential marketing, then the technology-sharing-experiential marketing (TSE) model was constructed based on relevant research. Finally, through seminars, the relationships indicated in the research model were established as hypotheses, as shown in Figure 1.

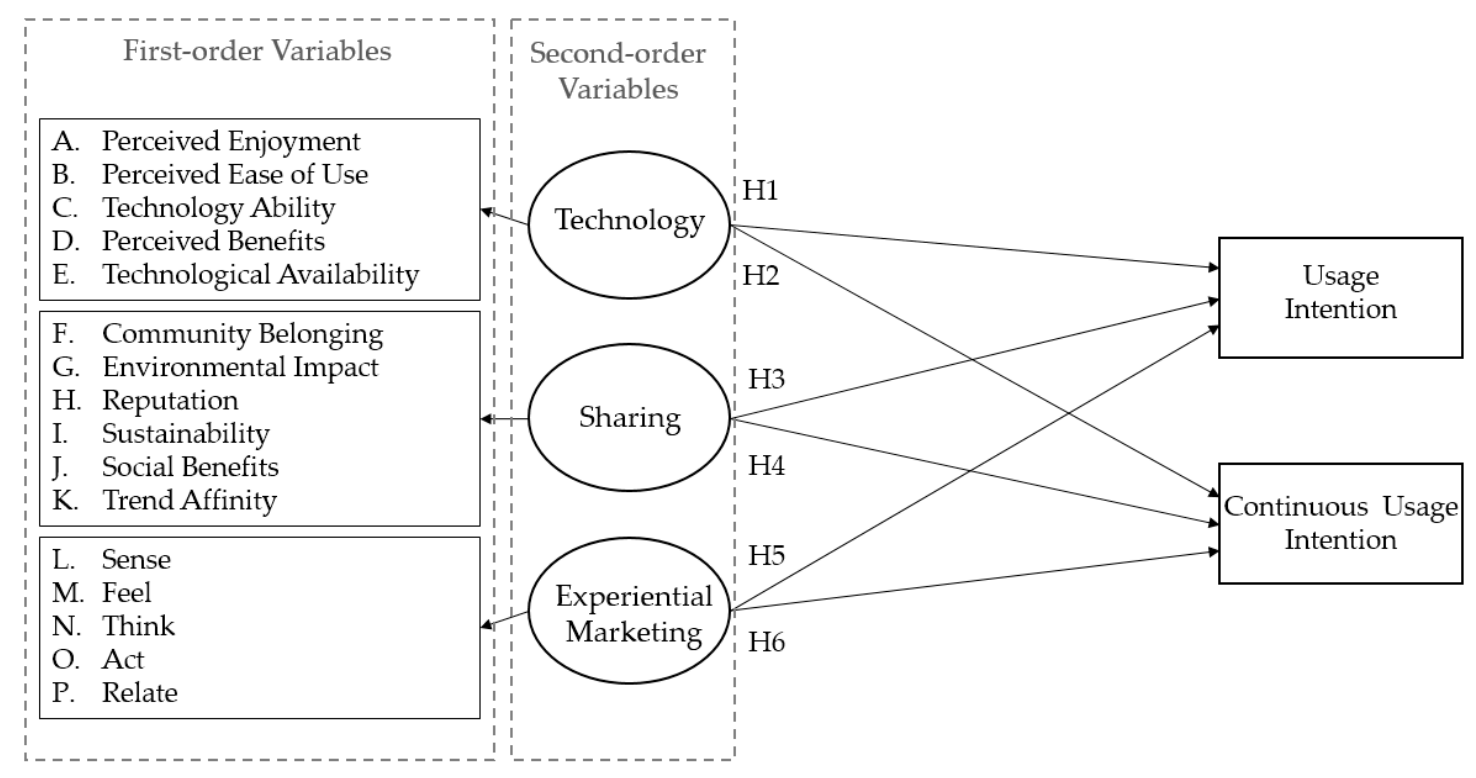

Figure 1. Research model.

Many past studies have revealed that the incompatibility between new technology and existing value or work will seriously discourage people from using innovative technology [58,59]. Furthermore, difficulty in understanding and operating new technology will also hinder continuous usage $[60,61]$. In addition, users' familiarity with the system will induce them to unconsciously interact with it, which increases their continuous usage intention [58]. In general, as an innovative information technology, the technological characteristics of the GRT system are regarded as incentives that will significantly affect users' usage and continuous usage intention. Therefore, the following hypothesis is proposed in this study:

Hypothesis 1 \& 2 (H1, H2). Technology has a significant impact on usage intention and continuous usage intention with regard to GRT. 
Many previous studies have revealed a positive relationship between sharing and continuous usage. Moeller and Wittkowski [53] pointed out that younger consumers tend to share ownership when they follow trendy, innovative, and fashionable products or services. Therefore, the sharing economy has a positive impact on ecological sustainability, and that concept arouses users' continuous usage intention [48]. In recent years, environmental awareness has been on the rise, while anti-consumption, environmental protection, and sustainable alternative consumption have received increasing attention. Many studies have found that environmental protection factors affect people's willingness to participate in sharing consumption [42-46]. Based on that, this study suggests that the sharing economy significantly affects users' usage intention and continuous usage intention. Therefore, the following hypothesis is proposed:

Hypothesis 3 \& $4 \mathbf{( H 3}, \mathbf{H 4})$. Sharing has a significant impact on usage intention and continuous usage intention with regard to GRT.

Yoon, Duff, and Ryu [12] divided the factors that affect users' continuous usage of a system into two categories: external and internal motivation. Specifically, Legault [57] claimed that internal motivation arises when participation behaviors are satisfying or pleasing. Tsiotsou et al. [62] found that experiential marketing can improve users' satisfaction with a service and increase their willingness to keep using it in the future, which creates a competitive advantage. When Luo et al. [63] studied the relationship between online marketing and purchase behaviors, they discovered that experiential marketing not only remarkably increases consumers' purchase intention and loyalty, but also affects commodity prices. Moreover, many studies suggested that technology providers should simultaneously provide basic services or functions and value to users. This value can stimulate user participation, satisfaction, and acceptance of new technologies $[58,64,65]$. Hence, the following hypothesis is proposed:

Hypothesis 5 \& $\mathbf{6}(\mathbf{H 5}, \mathbf{H 6})$. Experiential marketing has a significant impact on usage intention and continuous usage intention with regard to GRT.

\section{Data Analysis}

In this study, a questionnaire survey was conducted with people who have used GRT before. A questionnaire pretest was given before the survey. A total of five academic and industry experts were invited to revise the questionnaire. After that, the questionnaire was distributed in paper form in the experiential ride area of the Taipei World Trade Center and the Industrial Research Institute. A total of 357 questionnaires were recovered over a five-month period, of which 306 were valid.

\subsection{Descriptive Statistics}

In the descriptive statistics of this study, the gender ratio of respondents is about 58:42, men to women. Most respondents were $\leq 29$ years old, accounting for $25.5 \%$. The second-largest age group was 35 to 39 years old, at $17.0 \%$. For means of commuting, $61.4 \%$ of respondents took public transportation, $31.4 \%$ drove cars or rode motorcycles, and $6.2 \%$ walked or cycled.

\subsection{Factor Analysis}

The main purpose of factor analysis is to simplify data and establish a structure, and to streamline several variables into a few meaningful factors. It is one of the most effective ways to improve the construct validity of a questionnaire and further reveal the effective question items. There are two factor analysis methods: exploratory factor analysis (EFA) and confirmatory factor analysis (CFA).

EFA is mostly used in the development or preparation of scales to understand which indicators (items) should be selected or deleted, and which factors (or subscales) a dimension (latent variable) should include. CFA is mostly used after a scale is developed to verify whether specific indicators 
(questions) are consistent with the dimensions identified in existing theories. Therefore, theoretical verification is the main purpose of CFA.

This study intended to explore the relationship between observation indicators and potential items so as to verify the proposed structural equation model. Therefore, confirmatory factor analysis was used. For verification, Hair et al. [66] suggested that factor loadings greater than 0.7 are ideal and factor loadings greater than 0.6 are acceptable. As shown in Table 1, the confirmatory factor analysis results of this study show that the factor loadings of all items were greater than 0.6 , thus, they all reached a significant level.

Table 1. Questionnaire items, factor loading, and composite reliability (CR) value of each variable. GRT, group rapid transit.

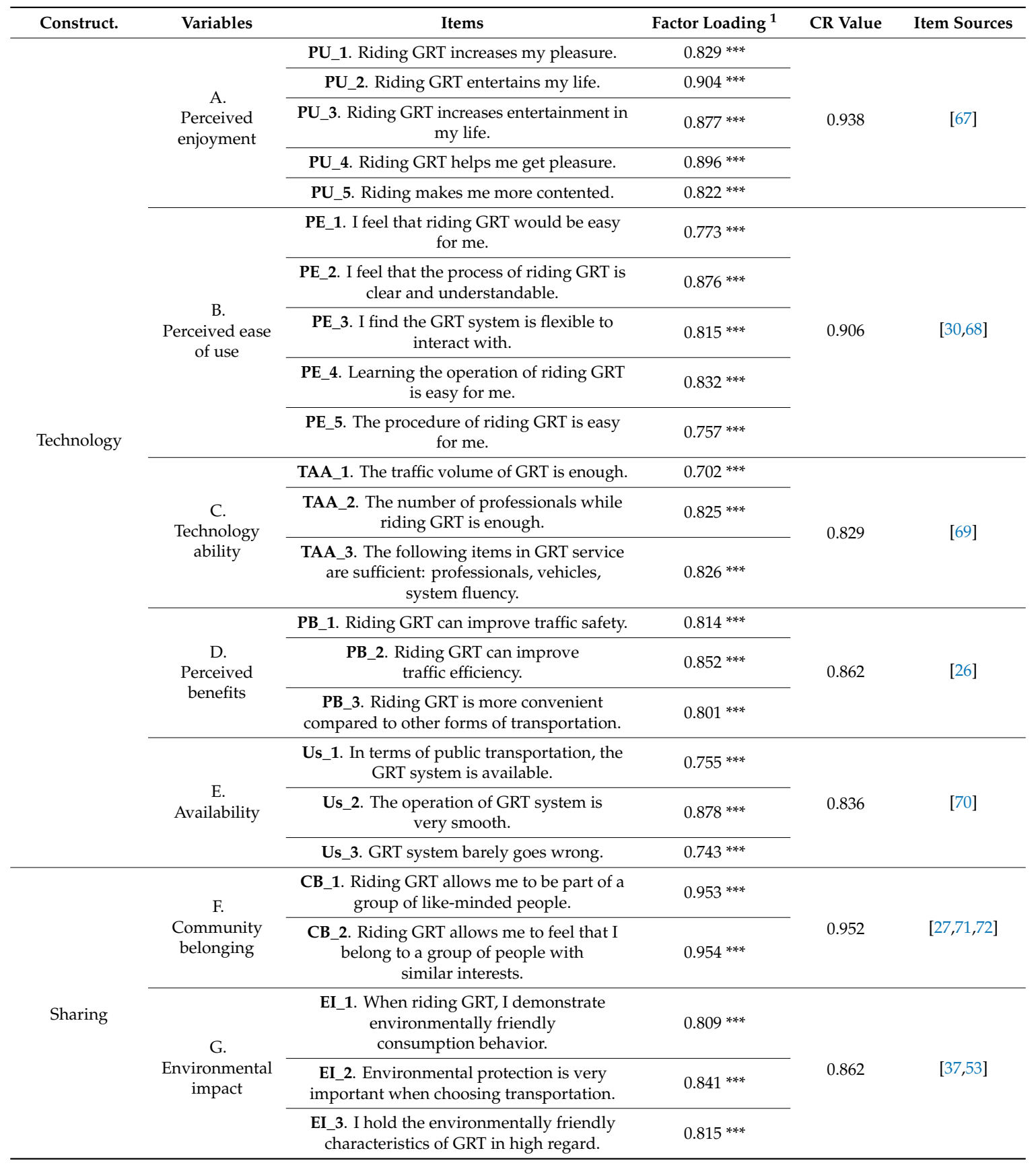


Table 1. Cont.

\begin{tabular}{|c|c|c|c|c|c|}
\hline Construct. & Variables & Items & Factor Loading ${ }^{1}$ & CR Value & Item Sources \\
\hline & \multirow{3}{*}{$\begin{array}{c}\text { H. } \\
\text { Reputation }\end{array}$} & $\begin{array}{l}\text { Re_1. Riding GRT improves my image } \\
\text { within the community. }\end{array}$ & $0.873 * * *$ & \multirow{3}{*}{0.902} & \multirow{3}{*}[35]{} \\
\hline & & $\begin{array}{l}\text { Re_3. I earn respect from others by sharing } \\
\text { my experience of riding GRT with } \\
\text { other people. }\end{array}$ & $0.848^{* * *}$ & & \\
\hline & & $\begin{array}{l}\text { Re_4. People in the community who have } \\
\text { ridden GRT have more prestige than those } \\
\text { who have not. }\end{array}$ & $0.777 * * *$ & & \\
\hline & \multirow{2}{*}{$\begin{array}{l}\text { I. } \\
\text { Sustainability }\end{array}$} & $\begin{array}{l}\text { Su_1. Riding GRT helps save } \\
\text { natural resources. }\end{array}$ & $0.808^{* * *}$ & \multirow{2}{*}{0.900} & \multirow{2}{*}{ [35] } \\
\hline & & $\begin{array}{l}\text { Su_4. Riding GRT is } \\
\text { environmentally friendly. }\end{array}$ & $0.832 * * *$ & & \\
\hline & \multirow{3}{*}{$\begin{array}{c}\text { J. } \\
\text { Social benefits }\end{array}$} & $\begin{array}{l}\text { SB_1. I am familiar with the employees who } \\
\text { operate the GRT service. }\end{array}$ & $0.903 * * *$ & \multirow{3}{*}{0.934} & \multirow{3}{*}[73,74]{} \\
\hline & & $\begin{array}{l}\text { SB_2. I have developed a friendship with } \\
\text { service provider of GRT. }\end{array}$ & $0.929 * * *$ & & \\
\hline & & $\begin{array}{l}\text { SB_3. The passengers of the GRT service } \\
\text { recognize me. }\end{array}$ & $0.891^{* * *}$ & & \\
\hline & $\begin{array}{l}\text { K. } \\
\text { Trend affinity }\end{array}$ & $\begin{array}{l}\text { TA_1. It is important for me to ride the } \\
\text { newest vehicles. }\end{array}$ & $0.822 * * *$ & 0.873 & {$[35,53]$} \\
\hline \multirow{12}{*}{$\begin{array}{l}\text { Experiential } \\
\text { Marketing }\end{array}$} & \multirow{2}{*}{$\begin{array}{l}\text { M. } \\
\text { Feel }\end{array}$} & FE_1. Riding GRT puts me in a certain mood. & $0.935^{* * *}$ & \multirow{2}{*}{0.934} & \multirow{9}{*}[75,76]{} \\
\hline & & FE_2. Riding GRT makes me emotional. & $0.937^{* * *}$ & & \\
\hline & \multirow{3}{*}{$\begin{array}{l}\text { N. } \\
\text { Think }\end{array}$} & TE_1. Riding GRT intrigues me. & $0.795^{* * *}$ & \multirow{3}{*}{0.879} & \\
\hline & & TE_2. Riding GRT stimulates my curiosity. & $0.897^{* * *}$ & & \\
\hline & & $\begin{array}{l}\text { TE_3. Riding GRT stimulates my } \\
\text { creative thinking. }\end{array}$ & $0.831^{* * *}$ & & \\
\hline & \multirow{2}{*}{$\begin{array}{l}\text { O. } \\
\text { Act }\end{array}$} & $\begin{array}{l}\text { AE_1. I would like to take a photo of the } \\
\text { GRT system. }\end{array}$ & $0.868^{* * *}$ & \multirow{2}{*}{0.847} & \\
\hline & & $\begin{array}{l}\text { AE_2. I would like to share my experience of } \\
\text { riding GRT. }\end{array}$ & $0.847^{* * *}$ & & \\
\hline & \multirow{2}{*}{$\begin{array}{c}\text { P. } \\
\text { Relate }\end{array}$} & $\begin{array}{l}\text { REE_1. I would like to buy souvenirs related } \\
\text { to GRT. }\end{array}$ & $0.726^{* * *}$ & \multirow{2}{*}{0.782} & \\
\hline & & $\begin{array}{l}\text { REE_2. Riding GRT gives me a sense of } \\
\text { identity with ecological conservation. }\end{array}$ & $0.872 * * *$ & & \\
\hline & \multirow{3}{*}{$\begin{array}{l}\text { Q. } \\
\text { Usage intention }\end{array}$} & BI_1. I plan to ride GRT in the future. & $0.894^{* * *}$ & \multirow{3}{*}{0.928} & \multirow{3}{*}{ [69] } \\
\hline & & $\begin{array}{l}\text { BI_2. I plan to continuously ride GRT in } \\
\text { the future. }\end{array}$ & $0.915^{* * *}$ & & \\
\hline & & BI_3. I would love to ride GRT in the future. & $0.869^{* * *}$ & & \\
\hline
\end{tabular}




\subsection{Reliability Analysis}

Reliability is a measure of correctness or accuracy, while reliability analysis measures the reliability, consistency, and stability of a questionnaire [68]. There are many ways to check reliability, including Cronbach's $\alpha$, composite reliability (CR), and variance extracted.

In this study, composite reliability was used to test the reliability of the questionnaire and measure the consistency of the question items in each dimension. CR is a value between zero and one; a higher value corresponds to a higher proportion of true variation in the total variation and higher internal consistency. Fornell and Larcker [77] suggested that the CR of variables should be greater than 0.7. As shown in Table 1 , the CR values in this study are all higher than 0.7 , thus the questionnaire has high consistency and stability.

\subsection{Validity Analysis}

Validity refers to correctness, and higher validity of a questionnaire means that the test results can better show the true characteristics of the predicted object. Generally, validity can be divided into content and construct validity. Content validity refers to the degree to which the measuring instrument can adequately cover the topic. The measurement is quite subjective. If a questionnaire is compiled by referring to relevant past studies and it passes a pretest and trial test, then it has evidence of content validity.

Construct validity refers to the ability of questionnaire items to measure abstract characteristics and theoretical concepts. It is usually tested by convergent and discriminant validity. Convergent validity refers to the convergence of a construct, which means measuring whether related factors will fall into the same dimension based on factor loadings. According to Hair et al. [66], if the number of samples is small, the factor loadings must be larger to reach a significant level. Fornell and Larcker [77] suggested using average variance extracted (AVE) to measure construct validity. AVE calculates the ability of potential variables to explain the variance of measurement items. Generally, AVE must be greater than 0.5 [78]; a higher AVE represents higher reliability and convergence validity of the potential variable.

Discriminant validity confirms that the measured variables are indeed different constructs. Different variables are measured and the results are examined by correlation analysis. If the correlation between two variables is low, they have discriminant validity. According to the suggestion of Hair et al. [79], the correlation coefficient between two variables should be lower than the square root of the AVE of each variable. The results of this study show that AVE is greater than 0.5 and the square root of AVE of all variables is greater than their correlation coefficient (Table 2), thus the scale of this study is valid. Table 2 represents a correlation coefficient matrix while square root of AVE of all dimensions are shown in bold. 
Table 2. Average variance extracted (AVE) value, AVE square root value, and correlation coefficient of each variable.

\begin{tabular}{|c|c|c|c|c|c|c|c|c|c|c|c|c|c|c|c|c|c|c|c|}
\hline Variable & AVE & A & B & C & D & $\mathrm{E}$ & $\mathbf{F}$ & G & $\mathbf{H}$ & I & $\mathrm{J}$ & $\mathbf{K}$ & $\mathbf{L}$ & $\mathbf{M}$ & $\mathbf{N}$ & $\mathrm{O}$ & $\mathbf{P}$ & $Q$ & $\mathbf{R}$ \\
\hline A. Perceivedenjoyment & 0.750 & 0.866 & & & & & & & & & & & & & & & & & \\
\hline B. Perceivedeaseofuse & 0.659 & 0.355 & 0.812 & & & & & & & & & & & & & & & & \\
\hline C. Technologyability & 0.619 & 0.420 & 0.384 & 0.787 & & & & & & & & & & & & & & & \\
\hline D. Perceivedbenefits & 0.677 & 0.419 & 0.434 & 0.467 & 0.823 & & & & & & & & & & & & & & \\
\hline E. Availability & 0.631 & 0.438 & 0.576 & 0.410 & 0.582 & 0.794 & & & & & & & & & & & & & \\
\hline F. Communitybelonging & 0.909 & 0.456 & 0.368 & 0.449 & 0.333 & 0.303 & 0.953 & & & & & & & & & & & & \\
\hline G. Environmentalimpact & 0.675 & 0.411 & 0.338 & 0.238 & 0.486 & 0.384 & 0.252 & 0.822 & & & & & & & & & & & \\
\hline H. Reputation & 0.698 & 0.563 & 0.346 & 0.400 & 0.333 & 0.336 & 0.618 & 0.308 & 0.836 & & & & & & & & & & \\
\hline I. Sustainability & 0.693 & 0.416 & 0.362 & 0.324 & 0.485 & 0.360 & 0.317 & 0.661 & 0.367 & 0.833 & & & & & & & & & \\
\hline J. Socialbenefits & 0.824 & 0.374 & 0.254 & 0.379 & 0.265 & 0.222 & 0.450 & 0.092 & 0.533 & 0.225 & 0.908 & & & & & & & & \\
\hline K. Trendaffinity & 0.697 & 0.611 & 0.373 & 0.250 & 0.387 & 0.352 & 0.348 & 0.467 & 0.417 & 0.462 & 0.152 & 0.835 & & & & & & & \\
\hline L. Sense & 0.776 & 0.476 & 0.519 & 0.409 & 0.444 & 0.500 & 0.349 & 0.360 & 0.344 & 0.402 & 0.197 & 0.389 & 0.881 & & & & & & \\
\hline M. Feel & 0.876 & 0.563 & 0.277 & 0.405 & 0.369 & 0.291 & 0.421 & 0.237 & 0.476 & 0.267 & 0.449 & 0.324 & 0.458 & 0.936 & & & & & \\
\hline N. Think & 0.709 & 0.579 & 0.416 & 0.396 & 0.494 & 0.404 & 0.335 & 0.461 & 0.419 & 0.464 & 0.233 & 0.495 & 0.594 & 0.552 & 0.842 & & & & \\
\hline O. Act & 0.735 & 0.505 & 0.422 & 0.316 & 0.338 & 0.401 & 0.263 & 0.419 & 0.303 & 0.391 & 0.081 & 0.486 & 0.557 & 0.354 & 0.664 & 0.857 & & & \\
\hline P. Relate & 0.644 & 0.533 & 0.427 & 0.411 & 0.467 & 0.515 & 0.385 & 0.490 & 0.462 & 0.488 & 0.300 & 0.403 & 0.438 & 0.402 & 0.531 & 0.573 & 0.803 & & \\
\hline Q. Usageintention & 0.763 & 0.399 & 0.411 & 0.258 & 0.476 & 0.470 & 0.144 & 0.572 & 0.275 & 0.521 & 0.094 & 0.429 & 0.449 & 0.273 & 0.491 & 0.551 & 0.630 & 0.873 & \\
\hline R. Continuoususageintention & 0.725 & 0.453 & 0.417 & 0.412 & 0.549 & 0.500 & 0.348 & 0.425 & 0.427 & 0.438 & 0.318 & 0.347 & 0.383 & 0.387 & 0.513 & 0.430 & 0.573 & 0.625 & 0.851 \\
\hline
\end{tabular}




\subsection{Structural Equation Modeling}

Smart PLS (Partial Least Squares) was used to test the model proposed in this study and bootstrapping was the analysis method mainly used to estimate the path coefficient. The reason for using PLS is that it is suitable for verifying models with a small or medium sample size. Figure 2 shows the path analysis diagram generated by the results of structural model analysis.

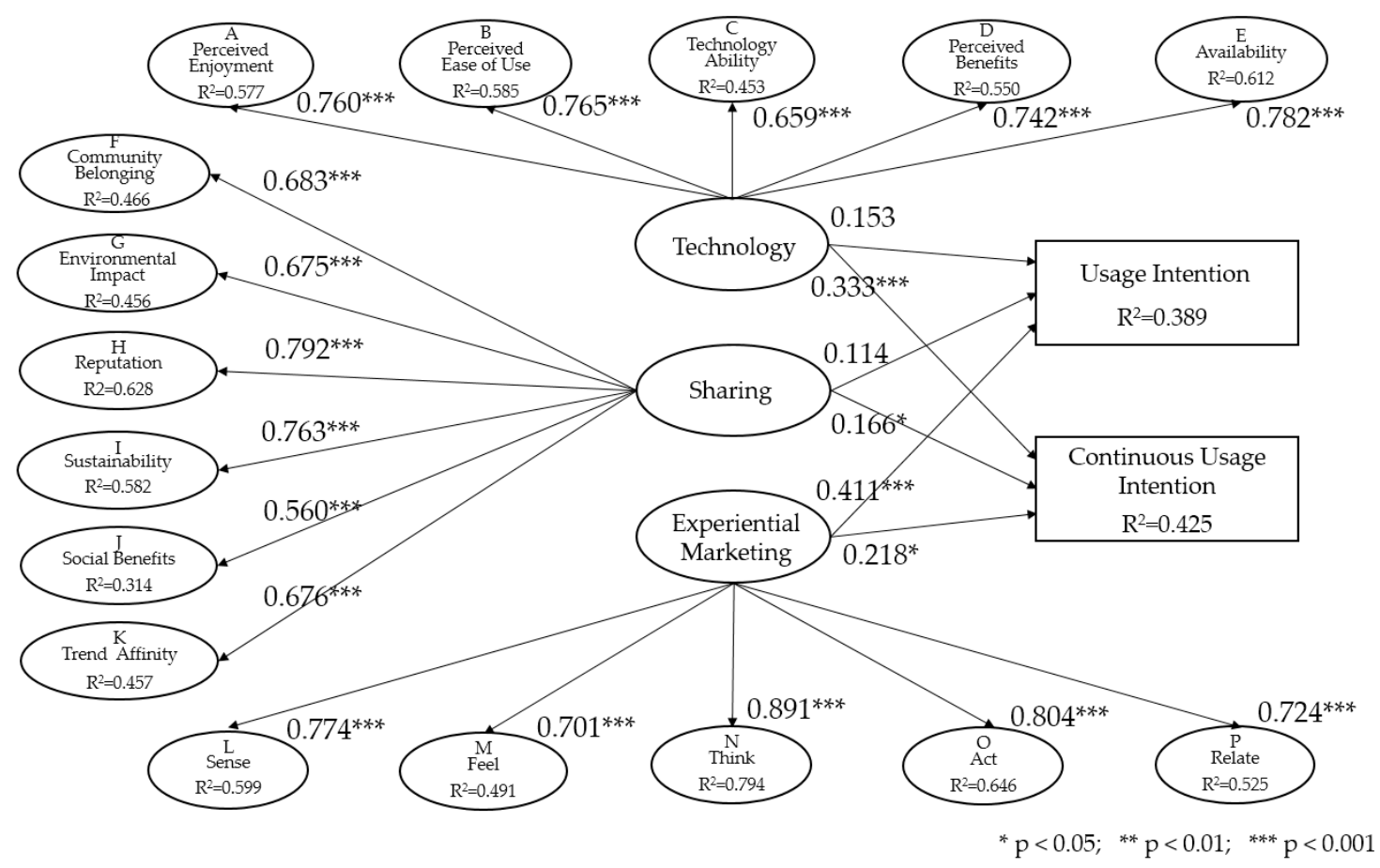

Figure 2. Result of path analysis with structural equation modeling.

In the SEM model, when the $\mathrm{t}$-value of the relationship between two variables is higher than 1.96 , the $p$-value reaches a significance level of 0.05 , which is represented by ${ }^{*}$. When the $\mathrm{t}$-value is higher than 2.58 , the $p$-value reaches a significance level of 0.01 , which is represented by ${ }^{* *}$. When the $\mathrm{t}$-value is higher than 3.29 , the $p$-value reaches a significance level of 0.001 , which is represented by ${ }^{* * *}$. Figure 2 shows the significance of each path coefficient. The data show that technology, sharing, and experiential marketing significantly affect usage intention and continuous usage intention with regard to GRT.

As shown in Table 3, the path coefficient of technology to usage intention is 0.153 and the t-value is 1.208 , which does not reach statistical significance. Technology does not have a significant impact on people's intention to use GRT, hence H1 is not valid. The path coefficient of technology to continuous usage intention is 0.333 , with a t-value of 3.426, which reaches significance. Therefore, $\mathrm{H} 2$ is established; technology has a significant impact on people's continuous intention to use GRT. 
Table 3. Hypothesis testing of research model.

\begin{tabular}{ccccc}
\hline Path & Hypothesis & Path Coefficient & T-Value (Significance Level) & Result \\
\hline $\begin{array}{c}\text { Technology } \rightarrow \\
\text { usage intention }\end{array}$ & $\mathrm{H} 1$ & 0.153 & $1.208(-)$ & Invalid \\
\hline $\begin{array}{c}\text { Technology } \rightarrow \\
\text { continuous usage intention }\end{array}$ & $\mathrm{H} 2$ & 0.333 & $3.426\left(^{* * *}\right)$ & Valid \\
\hline $\begin{array}{c}\text { Sharing } \rightarrow \\
\text { usage intention }\end{array}$ & $\mathrm{H} 3$ & 0.114 & $1.197(-)$ & Invalid \\
\hline $\begin{array}{c}\text { Sharing } \rightarrow \\
\text { continuous usage intention }\end{array}$ & $\mathrm{H} 4$ & 0.166 & $2.041\left(^{*}\right)$ & Valid \\
\hline $\begin{array}{c}\text { Experiential marketing } \rightarrow \\
\text { usage intention }\end{array}$ & $\mathrm{H} 5$ & 0.411 & $4.396\left(^{* * *}\right)$ & Valid \\
\hline $\begin{array}{c}\text { Experiential marketing } \rightarrow \\
\text { continuous usage intention }\end{array}$ & $\mathrm{H} 6$ & 0.218 & $2.329\left(^{*}\right)$ & Valid \\
\hline & $* p<0.05 ; * * 0.01 ; * * *<0.001$. & &
\end{tabular}

Sharing has a path coefficient of 0.114 for usage intention, and the $t$-value is 1.197 , which is not statistically significant. Hence, H3 is not valid; sharing does not have a significant impact on the intention to use GRT. The path coefficient of sharing to continuous usage intention is 0.166 and the $\mathrm{t}$-value is 2.041, which reaches a significant level. Thus, $\mathrm{H} 4$ is established, meaning that sharing has a significant impact on continuous intention to use GRT.

The path coefficient of experience to usage intention and continuous usage intention is 0.411 and 0.218 , with t-values of 4.396 and 2.329 , respectively. Since both t-values reach significance, H5 and $\mathrm{H} 6$ are established. Hence, experiential marketing has a significant impact on usage intention and continuous usage intention with regard to GRT.

\section{Conclusions}

This study adopted an innovative technology acceptance model to analyze the dimensions of technology, sharing, and experiential marketing. It further established a second-order model to further verify and discover users' acceptance of innovative transport services. Currently, studies on GRT, autopilot vehicles, and technology acceptance models are quite scarce, and many new aspects of technology acceptance have not been explored. The promotion of GRT service for public accessibility is an important research topic. Therefore, in this study, the factors related to introducing GRT service to Taiwan were analyzed and six hypotheses for the dimensions of technology, sharing, and experiential marketing were proposed. Through literature review, interviews with experts, questionnaire surveys, structural equation modeling (SEM), and Smart PLS analysis, the technology acceptance model and key factors influencing the usage of GRT service were summarized.

\subsection{Implications}

In the technology construct, perceived ease of use and availability are more important than other variables. This implies that in terms of innovative GRT service, technology must be simple and easy for users in order to lower their learning threshold and be useful in daily life. It is recommended that the government actively establish a GRT transportation sharing network. If the transportation network is not dense enough, it will cause inconvenience or be too expensive. Clearly, such inconvenience or high cost inhibits promotion of the service and will cause difficulties in the initial stages of its development. Moreover, one of the key factors of technology that enables the sustainable development of GRT is safety. GRT service should have long-term and comprehensive safety plans that should be improved upon regularly. However, technology has no significant impact on usage intention, because people's acceptance of emerging technologies increases over time. While people might not be familiar with innovative technology, they do not have strong usage intention. In contrast, it is speculated that 
long-term continuous usage intention is constructed by the trust of long-term passengers, thus the correlation between technology and GRT service cannot be ignored in long-term development.

In terms of sharing, reputation has an important impact. It is recommended that the government pay special attention to building a positive image for GRT service. For example, publicity activities can be introduced to popularize the environmentally friendly and energy-saving characteristics of GRT. In addition, innovative GRT services can be promoted in group media according to different age groups to set trends, which will be more effective than government promotion alone. Moreover, public figures or opinion leaders can be invited to promote services, forming a trend-following phenomenon and contributing to the promotion of innovative services. From the perspective of the TSE model, the sharing economy does not have a significant impact on usage intention, but it does on continuous usage intention. This means that the sharing economy is more helpful for long-term than short-term development, presumably because users need time to accept innovative technologies and services, and the immediate effects on the data are not obvious.

While experiential marketing does not have a significant impact on short-term usage intention or long-term continuous usage intention, during the promotion of innovative services, experiential activities can help construct consumers' service blueprint and increase their trust and support. It is suggested that the government organize more test ride activities and related supporting activities that attract crowds, such as raffles, check-ins, and ride-sharing experiences. Finally, the hypothesis verification shows that technology, sharing, and experiential marketing have certain effects on continuous usage, which also refers to the long-term development of innovative services.

This study proposes a new technology model that combined $\mathrm{T}, \mathrm{S}$, and $\mathrm{E}$ dimensions to make up the deficiency of studies on technology acceptance models in innovative autopilot services. Furthermore, it provides guidance for the development of such innovative services. We conducted a review of domestic and foreign literature to examine the development of GRT transportation and the dimensions of sharing, technology, and experiential marketing. Based on research data, we also identified the variables of the model to verify their correlation and representativeness with regard to the research problem. Although usage and continuous usage were completely introduced in past studies, most of the studies were applied to networks and information systems [10-13], and there have not been studies on the innovative services of GRT. Therefore, the model and variables constructed in this study have certain value. Final hypothesis verification shows that most of the hypotheses are consistent with past studies, which proves that the relevant principles in the past can be applied in the context of GRT.

\subsection{Limitations and Future Research}

First, in this study, only the opinions of GRT service users were discussed, and the opinions of managers and bus operators were not included. GRT managers and passenger transport operators may have different opinions on the subsequent operation of autopilot vehicles, and the implementation of GRT services will be affected by their opinions and ideas. It is recommended that more viewpoints be included in the future, and that qualitative interviews be conducted to explore more diverse topics.

Since the GRT service is currently at the trial operation stage and the service is not yet officially operating, very few users have really experienced the service and the service model has not yet been clarified. Further discussions to determine how to operate the GRT service should be carried out in the future. Most of the questionnaire respondents in this study are expected to keep using GRT in the initial stage when the commuting service is comprehensive. At that time, more in-depth research on continuous usage intention can be conducted.

Author Contributions: W.-H.H. conducted the literature review and was involved in the data collection, data analysis, and results discussions; Y.-T.H. drafted the manuscript and was involved in the results discussions. All authors have read and agreed to the published version of the manuscript.

Funding: The authors are grateful for funding from NSC, 107-2410-H-004-091-MY2, for publication of this paper.

Conflicts of Interest: The authors declare no conflict of interest. 


\section{References}

1. Mejía-Duganda, S.; Hjelm, O.; Baas, L.; Ríos, R.A. Lessons from the spread of Bus Rapid Transit in Latin America. J. Clean. Prod. 2013, 50, 82-90. [CrossRef]

2. Chapman, H.; Chapman, M.; Ceder, A. A new architectural design of elevated small group automated rapid transit. J. Public Transp. 2011, 14, 63-87. [CrossRef]

3. Muller, P.J.; Andreasson, I.J. A Light Rail, Group Rapid Transit, Personal Rapid Transit Comparison. In Proceedings of the 16th International Conference on Automated People Movers and Automated Transit Systems, Tampa, FL, USA, 29 April-2 May 2018.

4. Open Gov. NTU to Test Group Rapid Transit Autonomous Vehicles on Smart Campus by 2019. 2018. Available online: https://opengovasia.com/ntu-to-test-group-rapid-transit-autonomous-vehicles-on-smartcampus-by-2019/ (accessed on 22 September 2020).

5. Intelligent Transport. Driverless Shuttle Trial Launched in Newcastle, Australia. 2020. Available online: https://www.intelligenttransport.com/transport-news/101817/driverless-shuttle-trial-launched-innewcastle-australia/ (accessed on 22 September 2020).

6. 2Getthere Admin. Memorandum of Understanding Signed for GRT system in Hsinchu, Taiwan. 2015. Available online: https://www.2getthere.eu/news/hsinchu-grt-signing/ (accessed on 22 September 2020).

7. DIGITIMES. Taiwan Market: EZ10 Driverless Electric Bus Begins Trial Run. 2017. Available online: http://www.digitimes.com/news/a20170712PD200.html (accessed on 22 September 2020).

8. Focus Taiwan. Taoyuan Airport to Try out Driverless Shuttle Service in 2020. 2019. Available online: https://focustaiwan.tw/society/201911260017 (accessed on 22 September 2020).

9. Tornatzky, L.G.; Fleischer, M. The Processes of Technological Innovation; Lexington Books: Lexington, MA, USA, 1990.

10. Van der Heijden, H. User acceptance of hedonic information systems. MIS Q. 2004, 28, 695-704. [CrossRef]

11. Sun, Y.; Jeyaraj, A. Information technology adoption and continuance: A longitudinal study of individuals' behavioral intentions. Inf. Manag. 2013, 50, 457-465. [CrossRef]

12. Yoon, G.; Duff, B.R.; Ryu, S. Gamers just want to have fun? Toward an understanding of the online game acceptance. J. Appl. Soc. Psychol. 2013, 43, 1814-1826. [CrossRef]

13. Hsiao, K.L.; Lin, K.Y.; Wang, Y.T.; Lee, C.H.; Zhang, Z.M. Continued use intention of lifestyle mobile applications: The Starbucks app in Taiwan. Electron. Libr. 2019, 37, 893-913. [CrossRef]

14. Lees-Miller, J.D. Minimising average passenger waiting time in personal rapid transit systems. Ann. Oper. Res. 2016, 236, 405-424. [CrossRef]

15. Zhao, R.; Moh, W.H. Development of new modality municipal public transportation for Guangzhou-Group rapid transit system as supplementary linkage from Guangzhou city center to its eastern tourism zone. Front. Eng. Manag. 2015, 2, 378-390. [CrossRef]

16. Fagnant, D.J.; Kockelman, K. Preparing a nation for autonomous vehicles: Opportunities, barriers and policy recommendations. Transp. Res. Part A Policy Pract. 2015, 77, 167-181. [CrossRef]

17. López-Lambas, M.E.; Alonso, A. The driverless bus: An analysis of public perceptions and acceptability. Sustainability 2019, 11, 4986. [CrossRef]

18. Nordhoff, S.; De Winter, J.; Kyriakidis, M.; Van Arem, B.; Happee, R. Acceptance of driverless vehicles: Results from a large cross-national questionnaire study. J. Adv. Transp. 2018, 2018, 1-22. [CrossRef]

19. Roche-Cerasi, I. Public acceptance of driverless shuttles in Norway. Transp. Res. Part F Traffic Psychol. Behav. 2019, 66, 162-183. [CrossRef]

20. Davis, F.D. A Technology Acceptance Model for Empirically Testing New End-User Information Systems: Theory and Results. Ph.D. Thesis, MIT Sloan School of Management, Cambridge, MA, USA, 1 January 1985.

21. Venkatesh, V.; Davis, F.D. A theoretical extension of the technology acceptance model: Four longitudinal field studies. Manag. Sci. 2000, 46, 186-204. [CrossRef]

22. Venkatesh, V.; Morris, M.G.; Davis, G.B.; Davis, F.D. User acceptance of information technology: Toward a unified view. MIS Q. 2003, 27, 425-478. [CrossRef]

23. Venkatesh, V.; Thong, J.Y.; Xu, X. Consumer acceptance and use of information technology: Extending the unified theory of acceptance and use of technology. MIS Q. 2012, 36, 157-178. [CrossRef]

24. Polites, G.L.; Karahanna, E. The embeddedness of information systems habits in organizational and individual level routines: Development and disruption. MIS Q. 2013, 37, 221-246. [CrossRef] 
25. Venkatesh, V. Where to go from here? Thoughts on future directions for research on individual-level technology adoption with a focus on decision making. Decis. Sci. 2006, 37, 497-518. [CrossRef]

26. Kuan, K.K.; Chau, P.Y. A perception-based model for EDI adoption in small businesses using a technology-organization-environment framework. Inf. Manag. 2001, 38, 507-521. [CrossRef]

27. Zhu, K.; Kraemer, K.; Xu, S. Electronic business adoption by European firms: A cross-country assessment of the facilitators and inhibitors. Eur. J. Inf. Syst. 2003, 12, 251-268. [CrossRef]

28. Hong, W.; Zhu, K. Migrating to internet-based e-commerce: Factors affecting ecommerce adoption and migration at the firm level. Inf. Manag. 2006, 43, 204-221. [CrossRef]

29. Praveena, K.; Thomas, S. Continuance intention to use Facebook: A study of perceived enjoyment and TAM. Bonfring Int. J. Ind. Eng. Manag. Sci. 2014, 4, 24-29.

30. Davis, F.D. Perceived usefulness, perceived ease of use, and user acceptance of information technology. MIS Q. 1989, 13, 319-340. [CrossRef]

31. Rogers, E.M. Diffusion of Innovations, 4th ed.; The Free Press: New York, NY, USA, 1995.

32. Burgelman, R.; Maidique, M.A.; Wheelweight, S.C. Strategic Management of Technology and Innovation; McGraw Hill: New York, NY, USA, 2004.

33. Luken, M.; Edenhofer, O.; Knopf, B.; Leimbach, M.; Luderer, G.; Bauer, N. The role of technological availability for the distributive impacts of climate change mitigation policy. Energy Policy 2010, 39, 6030-6039. [CrossRef]

34. Felson, M.; Spaeth, J.L. Community structure and collaborative consumption: A routine activity approach. Am. Behav. Sci. 1978, 21, 614-624. [CrossRef]

35. Hamari, J.; Sjöklint, M.; Ukkonen, A. The sharing economy: Why people participate in collaborative consumption. J. Assoc. Inf. Sci. Technol. 2016, 67, 2047-2059. [CrossRef]

36. Botsman, R.; Rogers, R. What's Mine Is Yours: The Rise of Collaborative Consumption; Harper Business: New York, NY, USA, 2011.

37. Möhlmann, M. Collaborative consumption: Determinants of satisfaction and the likelihood of using a sharing economy option again. J. Consum. Behav. 2015, 14, 193-207. [CrossRef]

38. Tussyadiah, I.P. An exploratory on drivers and deterrents of collaborative consumption in travel. In Information E Communication Technologies in Tourism; Tussyadiah, I., Inversini, A., Eds.; Springer: Cham, Switzerland, 2015; pp. 817-830.

39. Hwang, J.; Griffiths, M.A. Share more, drive less: Millennials value perception and behavioral intent in using collaborative consumption services. J. Consum. Mark. 2017, 34, 132-146. [CrossRef]

40. Galbreth, M.R.; Ghosh, B.; Shor, M. Social sharing of information goods: Implications for pricing and profits. Mark. Sci. 2012, 31, 603-620. [CrossRef]

41. Nelson, M.R.; Rademacher, M.A. From trash to treasure: Freecycle. org as a case of generalized reciprocity. In Advances in Consumer Research; McGill, A.L., Shavitt, S., Eds.; Association for Consumer Research: Duluth, MN, USA, 2009; Volume 36, p. 905.

42. Albinsson, P.A.; Perera, B.Y. Alternative marketplaces in the 21st century: Building community through sharing events. J. Consum. Behav. 2012, 11, 303-315. [CrossRef]

43. Albinsson, P.A.; Wolf, M.; Kopf, D.A. Anti-consumption in East Germany: Consumer resistance to hyperconsumption. J. Consum. Behav. 2010, 9, 412-425. [CrossRef]

44. Neilson, L.A. Boycott or buycott? Understanding political consumerism. J. Consum. Behav. 2010, 9, $214-227$. [CrossRef]

45. Ozanne, L.K.; Ballantine, P.W. Sharing as a form of anticonsumption: An examination of toy library users. J. Consum. Behav. 2010, 9, 485-498. [CrossRef]

46. Schuitema, G.; De Groot, J.I.M. Green consumerism: The influence of product attributes and values on purchasing intentions. J. Consum. Behav. 2014, 14, 57-59. [CrossRef]

47. Baghini, M.S.; Ismail, A.; Hafezi, M.H.; Seifabad, O.K.; Almansob, R.A. Bus rapid transit (BRT) system impacts to environmental quality. Res. J. Appl. Sci. Eng. Technol. 2014, 7, 1158-1164.

48. Hars, A.; Ou, S. Working for Free?-Motivations of Participating in Open Source Projects. In Proceedings of the 34th Hawaii International Conference on System Sciences, Maui, HI, USA, 6 January 2001.

49. Prothero, A.; Dobscha, S.; Freund, J.; Kilbourne, W.E.; Luchs, M.G.; Ozanne, L.K.; Thøgersen, J. Sustainable consumption: Opportunities for consumer research and public policy. J. Public Policy Mark. 2011, 30, 31-38. [CrossRef] 
50. Wagner, N.; Strulak-Wójcikiewicz, R.; Landowska, A. Trust in sharing economy business models from the perspective of customers in Szczecin, Poland. Sustainability 2019, 11, 6838. [CrossRef]

51. Ng, S.; David, M.E.; Dagger, T.S. Generating positive word-of-mouth in the service experience. Manag. Serv. Qual. Int. J. 2011, 21, 133-151. [CrossRef]

52. Ciion PR Newswire. Sustainable and Innovative Personal Transport Solutions-Strategic Analysis of Carsharing Market In Europe. 2010. Available online: https://www.prnewswire.com/news-releases/ sustainable-and-innovative-personal-transport-solutions---strategic-analysis-of-carsharing-market-ineurope-99742324.html (accessed on 22 September 2020).

53. Moeller, S.; Wittkowski, K. The burdens of ownership: Reasons for preferring renting. Manag. Serv. Qual. 2010, 20, 176-191. [CrossRef]

54. Schmitt, B.H. Experiential Marketing: How to Get Customers to Sense, Feel, Think, Act and Relate to Your Company and Brands; The Free Press: New York, NY, USA, 1999.

55. Ajjan, H.; Hartshorne, R.; Cao, Y.; Rodriguez, M. Continuance use intention of enterprise instant messaging: A knowledge management perspective. Behav. Inf. Technol. 2014, 33, 678-692. [CrossRef]

56. Liébana-Cabanillas, F.; García-Maroto, I.; Muñoz-Leiva, F.; Ramos de Luna, I. Mobile payment adoption in the age of digital transformation: The case of Apple Pay. Sustainability 2020, 12, 5443. [CrossRef]

57. Legault, L. Intrinsic and extrinsic motivation. In Encyclopedia of Personality and Individual Difference; Zeigler-Hill, V., Shackelford, T.K., Eds.; Springer: Cham, Switzerland, 2016; pp. 1-4.

58. Jung, H.S.; Kim, K.H.; Lee, C.H. Influences of perceived product innovation upon usage behavior for MMORPG: Product capability, technology capability, and user centered design. J. Bus. Res. 2014, 67, 2171-2178. [CrossRef]

59. Kwon, T.H.; Zmud, R.W. Unifying the fragmented models of information systems implementation. In Critical Issues in Information Systems Research; Boland, R.J., Hirschheim, R.A., Eds.; John Wiley \& Sons, Inc.: Hoboken, NJ, USA, 1987; pp. 227-251.

60. Hoehle, H.; Zhang, X.; Venkatesh, V. An espoused cultural perspective to understand continued intention to use mobile applications: A four-country study of mobile social media application usability. Eur. J. Inf. Syst. 2015, 24, 337-359. [CrossRef]

61. Lee, S.; Kim, K.J. Factors affecting the implementation success of internet-based information systems. Comput. Hum. Behav. 2007, 23, 1853-1880. [CrossRef]

62. Tsiotsou, R.H.; Ratten, V.; Tsiotsou, R. Future research directions in tourism marketing. Mark. Intell. Plan. 2010, 28, 533-544. [CrossRef]

63. Luo, M.M.; Chen, J.S.; Ching, K.H.; Liu, C.C. An examination of the effects of virtual experiential marketing on online customer intentions and loyalty. Serv. Ind. J. 2010, 31, 2163-2191. [CrossRef]

64. Ahn, J.M.; Koo, D.M.; Chang, H.S. Different impacts of normative influences on proenvironmental purchasing behavior explained by differences in individual characteristics. J. Glob. Sch. Mark. Sci. 2012, 22, 163-182.

65. Hart, S.; Jan Hultink, E.; Tzokas, N.; Commandeur, H.R. Industrial companies' evaluation criteria in new product development gates. J. Prod. Innov. Manag. 2003, 20, 22-36. [CrossRef]

66. Hair, J.F.; Black, W.C.; Babin, B.J.; Anderson, R.E. Multivariate Data Analysis, 7th ed.; Pearson Prentice Hall: Upper Saddle River, NJ, USA, 2009.

67. Bhattacherjee, A. Understanding Information Systems Continuance: An Expectation-Confirmation Model. MIS Q. 2001, 25, 351-370. [CrossRef]

68. Alharbi, S.; Drew, S. Using the technology acceptance model in understanding academics' behavioural intention to use learning management systems. Int. J. Adv. Comput. Sci. Appl. 2014, 5, 143-155. [CrossRef]

69. Picoto, W.N.; Bélanger, F.; Palma-dos-Reis, A. A technology-organisation-environment (TOE)-based m-business value instrument. Int. J. Mob. Commun. 2014, 12, 78-101. [CrossRef]

70. Bradford, M.; Earp, J.B.; Grabski, S. Centralized end-to-end identity and access management and ERP systems: A multi-case analysis using the technology organization environment framework. Int. J. Account. Inf. Syst. 2014, 15, 149-165. [CrossRef]

71. Hennig-Thurau, T.; Henning, V.; Sattler, H. Consumer file sharing of motion pictures. J. Mark. 2007, 71, 1-18. [CrossRef]

72. Lamberton, C.P.; Rose, R.L. When is ours better than mine? A framework for understanding and altering participation in commercial sharing systems. J. Mark. 2012, 76, 109-125. [CrossRef] 
73. Bitner, M.J.; Gwinner, K.P.; Gremler, D.D. Relational benefits in services industries: The customer's perspective. J. Acad. Mark. Sci. 1998, 26, 101-114.

74. Yang, S.; Song, Y.; Chen, S.; Xia, X. Why are customers loyal in sharing-economy services? A relational benefits perspective. J. Serv. Mark. 2017, 31, 48-62. [CrossRef]

75. Brakus, J.J.; Schmitt, B.H.; Zarantonello, L. Brand experience: What is it? How is it measured? Does it affect loyalty? J. Mark. 2009, 73, 52-68. [CrossRef]

76. Tsaur, S.-H.; Chiu, Y.-T.; Wang, C.-H. The visitors behavioral consequences of experiential marketing: An empirical study on Taipei Zoo. J. Travel Tour. Mark. 2007, 21, 47-64. [CrossRef]

77. Kerlinger, F.N.; Lee, H.B. Foundations of Behavioral Research, 4th ed.; Wadsworth Thomson Learning: Belmont, CA, USA, 2000.

78. Fornell, C.; Larcker, D.F. Evaluating structural equation models with unobservable variables and measurement error. J. Mark. Res. 1981, 18, 39-50. [CrossRef]

79. Hair, J.F.; Black, W.C.; Babin, B.J.; Anderson, R.E.; Tatham, R.L. Multivariate Data Analysis, 6th ed.; Pearson Prentice Hall: Upper Saddle River, NJ, USA, 2006.

Publisher's Note: MDPI stays neutral with regard to jurisdictional claims in published maps and institutional affiliations.

(C) 2020 by the authors. Licensee MDPI, Basel, Switzerland. This article is an open access article distributed under the terms and conditions of the Creative Commons Attribution (CC BY) license (http://creativecommons.org/licenses/by/4.0/). 